\title{
Chemotaxonomic Differentiation of Coryneform Bacteria Isolated from Biofilters
}

\author{
BERND BENDINGER, ${ }^{1 *}$ REINER M. KROPPENSTEDT, ${ }^{2}$ STEFAN KLATTE, ${ }^{2}$ \\ AND KARLHEINZ ALTENDORF ${ }^{1}$ \\ Abteilung für Mikrobiologie, Universität Osnabrück, Barbarastrasse 11, D-4500 Osnabrück, ${ }^{1}$ and \\ DSM-Deutsche Sammlung von Mikroorganismen und Zellkulturen GmbH, \\ D-3300 Braunschweig, ${ }^{2}$ Germany
}

\begin{abstract}
Coryneform bacteria that were isolated from biofilters which are used for waste gas treatment of animal-rendering plant emissions were differentiated and partially identified by using chemotaxonomic methods. On the basis of the results of a numerical analysis of whole-cell fatty acid profiles, 79 isolates were divided into two major groups; the members of the first group contained saturated and monounsaturated fatty acids, whereas the members of the second group were characterized by iso- and anteiso-branched fatty acids. Division into subclusters was based mainly on quantitative differences in fatty acid composition and was confirmed by the results obtained for additional chemical markers (e.g., respiratory quinones, mycolic acids, polar lipids, cell wall amino acids, and whole-cell sugar patterns). By combining the results obtained for chemotaxonomic analyses that were performed for strains containing saturated and monounsaturated fatty acids, we were able to identify the genus Corynebacterium (two Corynebacterium species were differentiated on the basis of the occurrence of tuberculostearic acid), the genus Gordona, and the genus Mycobacterium. Among the strains that produced iso-anteiso fatty acid patterns, one subgroup was affiliated with the "nicotianae" group of the genus Arthrobacter; however, some strains contained a new combination of chemical markers. Peptidoglycan type A4a, L-Lys-Gly-L-Glu was combined with menaquinones MK-7 and MK-8, whereas peptidoglycan type A4a, L-LyS-L-Glu occurred together with MK-8 and MK-9. The second subgroup was characterized by a new type B peptidoglycan and MK-11, as well as small amounts of MK-12. Dififerentiation that was based first on chemotaxonomy and second on physiology gave reliable results. Thus, coryneform strains with new characteristics were isolated from biofilters.
\end{abstract}

Coryneform bacteria have been isolated from the packing material of biofilters that are used for waste gas treatment of animal-rendering plant emissions. These organisms represented a dominant part of the culturable, aerobic, heterotrophic bacterial flora if the waste gases contained a high organic carbon load of mainly carbonyl compounds (3). Valuable information for improving the efficiency and the long-term stability of the process can be derived from analyses of the naturally developing heterogeneous bacterial populations that are responsible for the degradation capacities of biofilters. Studies of the physiological properties of isolates, such as their degradative capacities or their ability to survive under the physicochemical conditions that exist in a biofilter, can disclose the relationship between waste gas composition and adapted bacterial flora. Further characterization of the isolated coryneform bacteria will extend our knowledge about whether these species exist in other habitats, such as wastewater treatment plants or soil, and whether highly specialized, potentially new species might be encountered in biofiltration plants. Therefore, rapid and reliable differentiation and identification methods which are applicable to a broad range of coryneform bacteria need to be established.

The coryneform bacteria that were isolated from biofilters by Hippchen (21) were identified only on a broad level by using morphological and physiological characters. Numerical analysis of cellular fatty acid compositions has been used successfully to differentiate and identify coryneform and nocardioform bacteria $(4,20)$. Bousfield et al. (4) emphasized the usefulness and wide applicability of this method for

\footnotetext{
* Corresponding author.
}

presumptive identification at the generic level. The taxon specificities of chemical markers for coryneform bacteria have been demonstrated for fatty acids $(26,45)$, isoprenoid quinones (10), polar lipids $(29,36)$, mycolic acids $(30,34)$, cell wall peptidoglycans $(1,38)$, and cell wall sugars $(31)$. A combination of chemotaxonomic and physiological methods has proven to be useful for identifying Nocardia isolates obtained from activated sludge (32).

In this study we evaluated the use of numerical analysis of whole-cell fatty acid profiles for the differentiation of a great number of unknown coryneform isolates. To extend the results obtained, we reexamined the fatty acid-based clusters by using additional chemotaxonomic markers. Moreover, we determined whether the chemotaxonomically based taxa could also be identified by using a restricted number of physiological tests.

(Some of the results have been published previously [3].)

\section{MATERIALS AND METHODS}

Chemicals. Unless otherwise stated, all of the chemicals were purchased from Merck, Darmstadt, Germany, or Riedel-de-Haën, Seelze, Germany.

Origins of strains and isolation procedure. The biofilters which we examined were used for biological odor abatement of malodorous waste gases at an animal-rendering plant. The waste gases had complex compositions and contained aldehydes, 2-ketones, fatty acids, furans, alkylsulfides, thiophenes, ammonia, and $\mathrm{H}_{2} \mathrm{~S}$ as constituent components $(2,3$, 47). The filters contained different packing materials, such as nonsterilized tree bark compost, tree bark, or polystyrene chips. A total of 12 samples were taken periodically between 1986 and 1989 from different experimental biofilters, as well 
TABLE 1. List of the 79 coryneform isolates obtained from biofilters and reference strains included in the six clusters on the fatty acid dendrogram

\begin{tabular}{|c|c|}
\hline FAME cluster & Strains \\
\hline 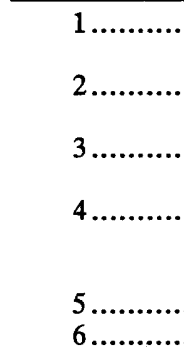 & 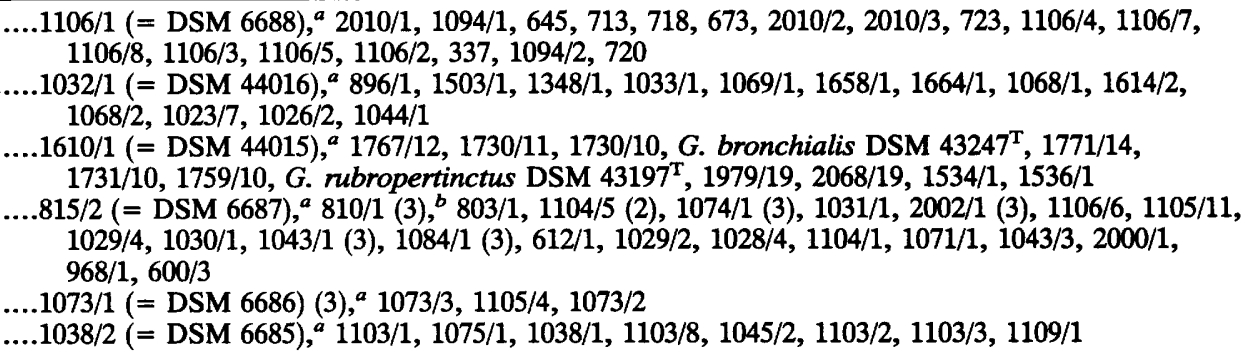 \\
\hline
\end{tabular}

a Strain was deposited in the DSM-Deutsche Sammlung von Mikroorganismen und Zellkulturen, GmbH, Braunschweig, Germany.

$b$ The numbers in parentheses are the numbers of fatty acid analyses performed for the strains included on the dendrogram.

as full-scale biofilters. One sample came from the liquid of a bioscrubber.

Strains were isolated by using agar plate culture techniques and wet-ground samples of filter material or samples that were obtained after enrichment in liquid media each containing filter material as the inoculum and one of the carbonyl compounds identified in the rendering emissions, as described previously (2). A total of 79 coryneform strains were selected on the basis of colony and cell morphology from the isolates obtained from different biofilters. The strain designations are shown in Table 1 . We used the following reference strains obtained from the DSM-Deutsche Sammlung von Mikroorganismen und Zellkulturen GmbH, Braunschweig, Germany: Corynebacterium pilosum DSM $20521^{\mathrm{T}}$ ( $\mathrm{T}=$ type strain), Corynebacterium flavescens DSM 20296 ${ }^{\mathrm{T}}$, Corynebacterium glutamicum DSM $20300^{\mathrm{T}}$, Corynebacterium renale DSM $20688^{\mathrm{T}}$, Corynebacterium xerosis DSM $20743^{\mathrm{T}}$, Rhodococcus rhodochrous DSM $43241^{\mathrm{T}}$, Gordona bronchialis DSM $43247^{\mathrm{T}}$, Gordona rubropertinctus DSM $43197^{\mathrm{T}}$, Nocardia asteroides DSM $43757^{\mathrm{T}}$, "Corynebacterium mediolanum" DSM 20152 (name not included on the Approved Lists of Bacterial Names [40] and later lists), Agromyces ramosus DSM $43045^{\mathrm{T}}$, Curtobacterium flaccumfaciens DSM 20129, Brevibacterium linens DSM $20425^{\mathrm{T}}$, Clavibacter michiganense DSM $20134^{\mathrm{T}}$, Curtobacterium citreum DSM $20528^{\mathrm{T}}$, Aureobacterium liquefaciens DSM $20638^{\mathrm{T}}$, and Microbacterium lacticum DSM $20427^{\mathrm{T}}$.

Cultivation. Lyophilized cell material was prepared from shake cultures that were grown in brain heart infusion broth (Difco Laboratories, Detroit, Mich.) at $30^{\circ} \mathrm{C}$ for 3 to 5 days. Cultures were checked for purity, harvested by centrifugation or filtration, washed twice with distilled water, and freeze-dried. For fatty acid analyses, strains were cultivated for 3 days at $30^{\circ} \mathrm{C}$, and samples (about $50 \mathrm{mg}$ ) of wet cell material were scraped off the surfaces of plates containing antibiotic sulfonamide sensitivity test agar (catalog no. 5392; Merck). Agromyces ramosus was grown on Trypticase soy broth (BBL Microbiology Systems, Cockeysville, Md.) supplemented with $0.5 \%$ yeast extract (Difco) and solidified with agar. Inocula for the physiological reactions that were tested on agar plates and in microtitration plates were taken from antibiotic sulfonamide sensitivity agar cultures that were incubated for 3 days at $30^{\circ} \mathrm{C}$.

Fatty acid analysis. The procedures used to prepare wholecell methanolysates, extract the fatty acid methyl esters (FAME), differentiate the FAME by gas-liquid chromatography, and quantify and identify the FAME have been described previously (27). Mycolic acid methyl esters were trapped by passing an extract through a silica gel column (Bond Elut column SI; catalog no. 601101; Analytichem International, Harbor City, Calif.). The qualitative and quantitative differences in the fatty acid patterns obtained from 114 analyses (79 isolates, with several isolates analyzed in duplicate or triplicate [Table 1], and 15 reference strains) were used to determine the Euclidian distances to each strain. All of the numerical analyses and the calculations for the FAME dendrogram were performed by using Microbial Identification System library-generating software (Microbial ID, Newark, Del.) and a model 9000 series 300 computer (Hewlett-Packard Co., Palo Alto, Calif.).

Isoprenoid quinones. Isoprenoid quinones were extracted and purified by using the small-scale integrated procedure of Minnikin et al. (35). For strains $1038 / 2$ and 1109/1, which synthesized only small amounts of isoprenoid quinones, extraction was done with chloroform-methanol (2:1, vol/vol) (15). For identification by high-performance liquid chromatography the procedure of Kroppenstedt et al. (27) was used.

Polar lipids. Polar lipids were extracted by using the small-scale integrated procedure of Minnikin et al. (35) and were separated by two-dimensional silica gel thin-layer chromatography (14). Phospholipids were detected by using the specific spray reagent molybdenum blue (Sigma, Deisenhofen, Germany), lipids with primary or secondary amino groups were detected by using ninhydrin, and sugar-containing lipids were detected by using anisaldehyde (Sigma)$\mathrm{H}_{2} \mathrm{SO}_{4}$. A green color indicated the presence of mannose and/or galactose residues, and a brown color indicated the presence of glucose residues.

Mycolic acids. Mycolic acids were separated as their methyl esters by using thin-layer chromatography (34). Methanolysis was performed at $75^{\circ} \mathrm{C}$ for $16 \mathrm{~h}$. For thin-layer chromatography we used Silica Gel 60 plates $(20$ by $20 \mathrm{~cm}$; thickness of the layer, $0.2 \mathrm{~mm}$; catalog no. 5553; Merck). Mycolic acids were detected by spraying the plates with molybdatophosphoric acid (Sigma). Chain lengths were determined by comparing the chromatographic mobilites of the mycolic acid methyl esters of the isolates with the chromatographic mobilities of the mycolic acid methyl esters of Corynebacterium glutamicum DSM $20300^{\mathrm{T}}$ or Corynebacterium pilosum DSM $20521^{\mathrm{T}}$ (corynemycolic acids), $R$. rhodochrous DSM $43241^{\mathrm{T}}$ (rhodomycolic acids), and $G$. rubropertinctus DSM $43197^{\mathrm{T}}, G$. bronchialis DSM $43247^{\mathrm{T}}$, or $N$. asteroides DSM $43757^{\mathrm{T}}$ (nocardomycolic acids). Eumycolates were detected on the basis of their greatest mobilities and multispot patterns (34).

Glycolic acid. The glycolic acid of a peptidoglycan was 
determined by using the colorimetric method of Uchida and Aida (46), modified by passing the hydrolysate through an ion exchanger (Bond Elut column SCX; catalog no. 617303; Analytichem).

Cell wall sugars. Cell wall sugars were detected in wholecell hydrolysates by the procedure of Lechevalier (28) as modified for thin-layer chromatography with cellulose plates (catalog no. 5577; Merck) by Stanek and Roberts (44). The solvent system used was ethyl acetate-pyridine-water (100: $35: 25$, vol/vol/vol) (24) with triple development.

Diamino acid. Whole-cell hydrolysates were used to detect meso-diaminopimelic acid $\left(m-\mathrm{A}_{2} \mathrm{pm}\right)$ by thin-layer chromatography (1). To detect other major diamino acids, purified cell walls were prepared by mechanical disruption with glass beads and by trypsin digestion (38). Subsequent thin-layer chromatography was performed as described previously for $m-\mathrm{A}_{2} \mathrm{pm}$.

Amino acid composition and sequence in the peptidoglycan. Complete acid hydrolysates of purified cell walls were examined by two-dimensional thin-layer chromatography (38). To calculate the molar ratios of the amino acids, complete acid hydrolysates were analyzed by using an automatic amino acid analyzer (model LC 5000; Biotronik, Munich, Germany). Partial acid hydrolysates were examined by two-dimensional thin-layer chromatography, and peptides were identified on the basis of their chromatographic mobilities and staining characteristics (38). The N-terminal amino acid of the interpeptide bridge was determined by dinitrophenylation of the undegraded peptidoglycan (38).

Physiology. The physiological tests used (see Table 6) were selected on the basis of the characteristics that are of diagnostic value in distinguishing the coryneform bacteria (39). For the carbon assimilation tests the method of Seiler (39) was used. The basal medium contained $50 \mathrm{ml}$ of $0.5 \mathrm{M}$ $\mathrm{KH}_{2} \mathrm{PO}_{4}-\mathrm{Na}_{2} \mathrm{HPO}_{4}(\mathrm{pH} 6.8), 6.7 \mathrm{~g}$ of yeast nitrogen base (Difco), $15 \mathrm{~g}$ of agar, and $1,000 \mathrm{ml}$ of deionized water. Since some strains had more complex nutritional requirements, the Corynebacterium isolates and the Corynebacterium reference strains were grown on medium containing $50 \mathrm{ml}$ of 0.5 $\mathrm{M} \mathrm{KH}{ }_{2} \mathrm{PO}_{4}-\mathrm{Na}_{2} \mathrm{HPO}_{4}$ (pH 6.8), $2.2 \mathrm{~g}$ of $\mathrm{NH}_{4} \mathrm{Cl}, 0.05 \mathrm{~g}$ of $\mathrm{KNO}_{3}, 0.2 \mathrm{~g}$ of $\mathrm{NaCl}, 0.35 \mathrm{~g}$ of $\mathrm{MgSO}_{4} \cdot 7 \mathrm{H}_{2} \mathrm{O}, 0.06 \mathrm{~g}$ of $\mathrm{CaCl}_{2} \cdot 2 \mathrm{H}_{2} \mathrm{O}, 0.01 \mathrm{~g}$ of $\mathrm{FeCl}_{3} \cdot 6 \mathrm{H}_{2} \mathrm{O}, 10 \mathrm{ml}$ of a vitamin solution (39), $0.1 \mathrm{~g}$ of yeast extract (GIBCO, Eggenstein, Germany), $0.15 \mathrm{~g}$ of Casamino Acids (Difco), $20 \mathrm{mg}$ of DL-methionine, $15 \mathrm{~g}$ of agar, and $1,000 \mathrm{ml}$ of deionized $\mathrm{H}_{2} \mathrm{O}$. The composition of this medium had no effect on the reactions recorded on yeast nitrogen base medium for selected Corynebacterium strains with tuberculostearic acid (TBSA), as well as Gordona and Mycobacterium strains. The final concentrations of carbon sources used for the utilization tests were $0.1 \%$ for organic acids and amino acids and $0.5 \%$ for carbohydrates. The basal medium was used as a control for growth. Tests for hydrolysis of aromatic compounds were performed by using each compound at a concentration of $0.5 \%$. Acid formation from sucrose and glucose was tested in liquid media containing bromcresol purple as a $\mathrm{pH}$ indicator (39). In the tests for aerobic acid formation the tubes were incubated in a normal atmosphere, but in the tests for anaerobic acid formation the tubes were sealed with paraffin. All test results were recorded after 2 weeks of incubation at $30^{\circ} \mathrm{C}$. A test was recorded as positive if growth greater than the growth of the control occurred in the utilization tests, if clearing zones were formed around the growth on agar plates containing aromatic compounds, or if the color changed from purple to yellow, indicating the formation of acid.

For 15 isolates and three reference strains belonging to the iso-anteiso fatty acid group, 37 additional physiological tests were performed in microtitration plates by using the methods of Lipski et al. (33). We tested hydrolysis of chromogenic substrates (see Table 7) and utilization of the following carbon sources: acetate, propionate, butyrate, isobutyrate, valerate, isovalerate, caproate, heptanoate, caprylate, DL-3hydroxybutyrate, lactate, pyruvate, citrate, malate, gluconate, fructose, D-ribose, and myo-inositol. To prevent evaporation, the test plates were covered with plastic sealers (Flow Laboratories, Mechenheim, Germany) which were perforated with a needle above each cavity and additionally covered with a lid. The plates were incubated for 7 days at $25^{\circ} \mathrm{C}$. The test results were interpreted photometrically as described by Lipski et al. (33), with the following modification: a carbon source utilization test was considered positive if the difference between the extinction at $410 \mathrm{~nm}$ for the test cavity and the extinction at $410 \mathrm{~nm}$ for the control cavity without a carbon source was equal to or greater than 0.05 .

\section{RESULTS}

Fatty acid analyses. The dendrogram based on the fatty acid compositions (Fig. 1) revealed that the isolated strains and the reference strains could be separated into six clusters at Euclidian distances ranging from 3 to 29 . However, most of the reference strains clustered separately. The mean fatty acid compositions of these clusters were calculated (Tables 2 and 3). Two major groups of strains which contained either mainly saturated and monounsaturated fatty acids or isoand anteiso-methyl-branched fatty acids were clearly separated at a Euclidian distance of 84 (Fig. 1). Each group was further divided into three clusters.

In the group of strains that produced saturated-unsaturated fatty acid patterns, cluster 1 was characterized by its high levels of octadecenoic acid (18:1-cis9) and hexadecanoic acid (16:0) (Table 2). Cluster 1 was clearly separated from clusters 2 and 3, whose strains contained the diagnostic compound TBSA (10-methyl 18:0). In these taxa 16:0 was the dominant fatty acid. An unsaturated 16:1 fatty acid, probably 16:1-cis 10 with an equivalent chain length (25) of 15.857, was also detected. Clusters 2 and 3 were differentiated only by quantitative differences in their fatty acid compositions (Table 2). Among the reference strains, Corynebacterium pilosum DSM $20521^{\mathrm{T}}$ grouped most closely, at a Euclidian distance of 11, with cluster 1 (a narrow cluster), which was defined at a Euclidian distance of 10 (Fig. 1). Other reference strains, such as Corynebacterium flavescens DSM $20296^{\mathrm{T}}$, Corynebacterium renale DSM $20688^{\mathrm{T}}$, and Corynebacterium glutamicum DSM $20300^{\mathrm{T}}$, were further from cluster 1. Corynebacterium xerosis DSM $20743^{\mathrm{T}}$ was separated in a single-member cluster closer to the TBSA-

FIG. 1. Dendrogram showing the relationships among the coryneform isolates obtained from the biofilters and reference strains. The dendrogram was based on quantitative fatty acid data obtained by using the Microbial Identification System. See Table 1 for the list of strains included in the clusters. The numbers in parentheses indicate the total numbers of repeated analyses performed for the clusters. For the names associated with the Deutsche Sammlung von Mikroorganismen und Zellkulturen (DSM) numbers see Materials and Methods. 


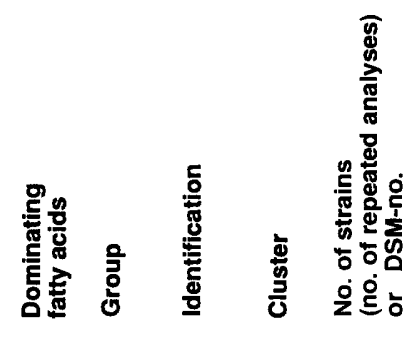

uclidian distance

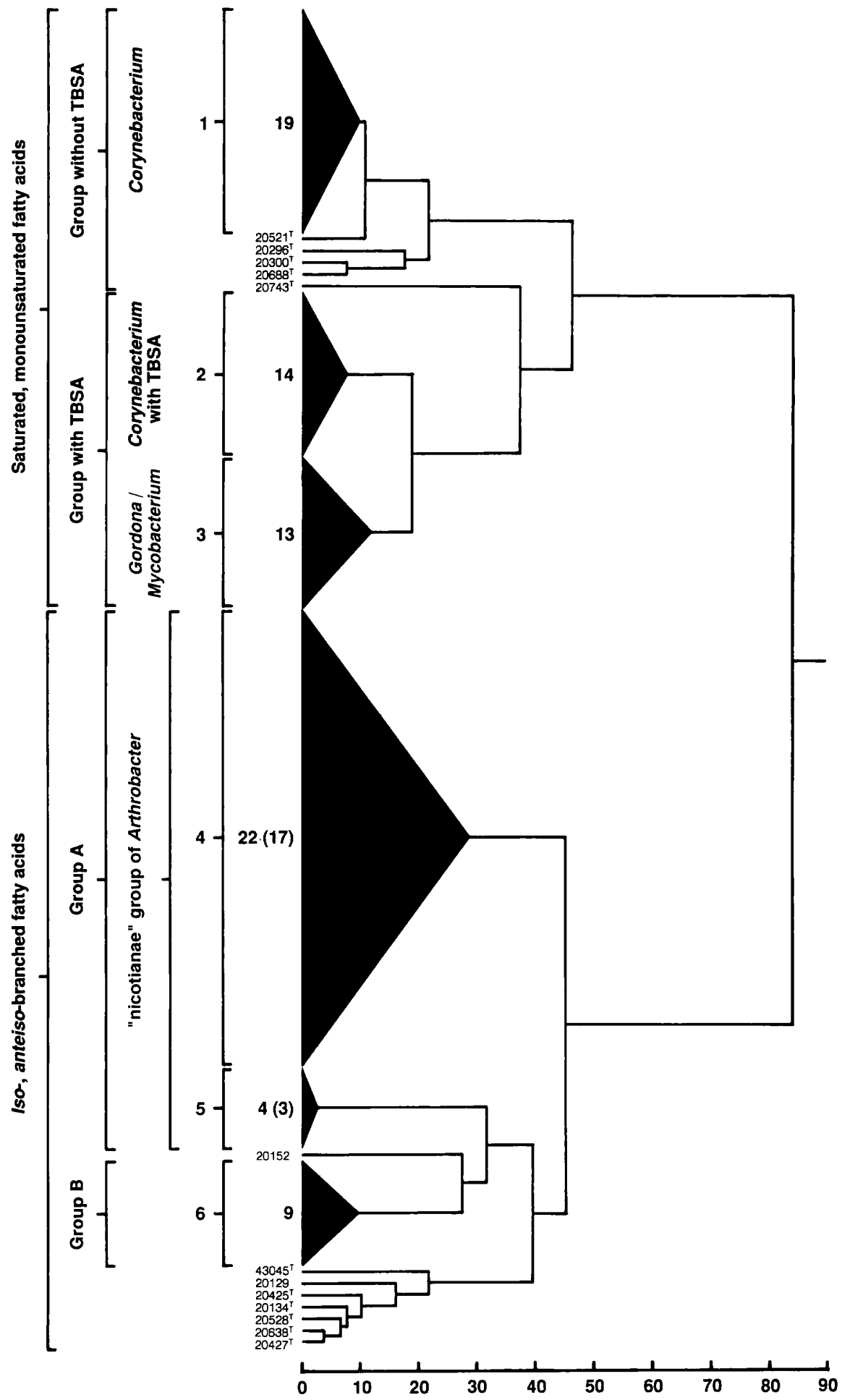


TABLE 2. Fatty acid compositions of clusters and reference strains that had saturated-unsaturated fatty acid patterns

\begin{tabular}{|c|c|c|c|c|c|c|c|c|c|c|c|c|c|}
\hline \multirow[b]{3}{*}{ Fatty acid } & \multicolumn{13}{|c|}{$\%$ in $^{a}:$} \\
\hline & \multicolumn{2}{|c|}{$\begin{array}{l}\text { Cluster } 1 \\
(n=19)^{b}\end{array}$} & \multicolumn{2}{|c|}{$\begin{array}{l}\text { Cluster } 2 \\
(n=14)\end{array}$} & \multicolumn{2}{|c|}{$\begin{array}{l}\text { Cluster } 3 \\
(n=13)\end{array}$} & \multicolumn{7}{|c|}{ Reference strains } \\
\hline & Mean $^{c}$ & Range & Mean & Range & Mean & Range & $\begin{array}{c}\text { Cory- } \\
\text { nebac- } \\
\text { terium } \\
\text { pi- } \\
\text { losum } \\
\text { DSM } \\
20521^{\mathrm{T}}\end{array}$ & $\begin{array}{c}\text { Cory- } \\
\text { nebac- } \\
\text { terium } \\
\text { fla- } \\
\text { vescens } \\
\text { DSM } \\
20296^{\mathrm{T}}\end{array}$ & $\begin{array}{c}\text { Cory- } \\
\text { nebac- } \\
\text { terium } \\
\text { glu- } \\
\text { tamicum } \\
\text { DSM } \\
20300^{\mathrm{T}}\end{array}$ & $\begin{array}{c}\text { Cory- } \\
\text { nebac- } \\
\text { terium } \\
\text { renale } \\
\text { DSM } \\
20688^{\mathrm{T}}\end{array}$ & $\begin{array}{l}\text { Cory- } \\
\text { nebac- } \\
\text { terium } \\
\text { xerosis } \\
\text { DSM } \\
20743^{\mathrm{T}}\end{array}$ & $\begin{array}{c}\text { G. bron- } \\
\text { chialis } \\
\text { DSM } \\
43247^{\mathrm{T}}\end{array}$ & $\begin{array}{c}\text { G. } n \text { - } \\
\text { broper- } \\
\text { tinctus } \\
\text { DSM } \\
43197^{T}\end{array}$ \\
\hline $\begin{array}{l}\text { Unknown ECL } \\
11.608^{d}\end{array}$ & $\mathbf{v}$ & $(01-0.4)^{e}$ & $\mathbf{V}$ & $(0-0.4)$ & - & - & - & 1.6 & - & - & 1.8 & - & - \\
\hline $\begin{array}{l}\text { Unknown ECL } \\
12.099\end{array}$ & 1.0 & $0-3.1$ & 0.8 & $0-2.2$ & 0.7 & $0-1.2$ & 0.7 & 0.6 & 1.4 & - & 0.6 & 0.5 & 1.0 \\
\hline $14: 0$ & - & - & 0.9 & $0.6-1.7$ & 2.4 & $1.8-4.0$ & 0.8 & 3.1 & 0.9 & - & - & 2.2 & 2.0 \\
\hline 15:0 & - & - & 2.1 & $1.2-3.9$ & 1.0 & $0-2.6$ & - & - & 1.0 & 0.4 & 2.7 & 2.6 & 0.8 \\
\hline $16: 1 \mathrm{~B}^{f}$ & - & - & $\mathrm{v}$ & $(0-0.5)$ & 0.8 & $0-3.5$ & 4.1 & 1.5 & 0.7 & - & 0.6 & 0.6 & 0.5 \\
\hline 16:1-cis9 & 1.7 & $0-4.2$ & 1.3 & $0.7-1.8$ & 1.0 & $0-5.4$ & - & - & - & - & - & - & - \\
\hline $\begin{array}{c}\text { ECL 15.857 (16: } \\
1 \text {-cis } 10)\end{array}$ & - & - & 6.7 & $3.9-11.1$ & 13.2 & $9.7-19.1$ & - & - & - & - & - & 11.0 & 14.8 \\
\hline $16: 0$ & 26.2 & $21.3-30.7$ & 36.0 & $30.8-39.2$ & 33.4 & $29.2-36.4$ & 27.2 & 33.9 & 41.4 & 42.3 & 10.0 & 30.6 & 29.2 \\
\hline $17: 1$ & $\mathrm{~V}$ & $(0-0.5)$ & 1.8 & $1.0-4.1$ & 1.9 & $0.4-4.5$ & - & - & - & - & 14.7 & 4.5 & 2.5 \\
\hline $17: 0$ & V & $(0-0.3)$ & 3.2 & $0-4.2$ & 1.8 & $0-6.0$ & - & - & 0.4 & - & 19.2 & 6.0 & 1.3 \\
\hline $\begin{array}{c}\text { ECL } 17.409(10- \\
\text { methyl-17:0) }\end{array}$ & - & - & 0.7 & $0-2.0$ & $\mathbf{v}$ & $(0-0.9)$ & - & - & - & - & - & 0.5 & - \\
\hline 18:1-cis 9 & 68.5 & $63.5-73.3$ & 19.0 & $14.6-23.4$ & 27.4 & $20.2-31.8$ & 62.2 & 54.7 & 53.4 & 51.7 & 36.7 & 29.3 & 30.2 \\
\hline 18:0 & 2.3 & $1.2-3.6$ & 1.7 & $0.9-2.7$ & 2.6 & $0-8.7$ & 4.3 & 4.6 & 0.7 & 5.6 & 13.0 & 3.6 & 0.9 \\
\hline 10-Methyl-18:0 & - & - & 25.4 & $20.5-28.0$ & 12.2 & $7.4-17.2$ & 0.8 & - & - & - & - & 7.4 & 11.1 \\
\hline 19:1-cis 10 & - & - & - & - & V & $(0-3.6)$ & - & - & - & - & 0.9 & 0.4 & 3.6 \\
\hline
\end{tabular}

a - not detected; $\mathrm{V}$, variable (see footnote $e$ ). In addition the following fatty acids were detected: cluster 1, 1.1 to 1.5\% 20:0 in strains 1094/1 and 1106/1 and $0.9 \% 20: 1$-cis 11 in strain $1106 / 1$; cluster 2,0 to $1.2 \%$ ECL 16.433 (10-methyl-16:0); cluster 3,0 to $0.3 \% 10: 0,0$ to $0.6 \%$ unknown ECL $13.961,0$ to $0.4 \% 15: 1$-cis 10 , and 0 to $0.2 \%$ unknown ECL 18.686; 0.6\% unknown ECL 16.407 in strains 1979/19 and 2068/19;0.3\% unknown ECL 11.608 in strain 1771/14; $0.8 \%$ unknown ECL 19.735 in G. nubropertinctus; and 0.9 to $1.4 \%$ unknown ECL 16.433 in strains $1534 / 1$ and $1536 / 1$.

${ }^{b} n$ is the number of strains included in a cluster (see Table 1).

${ }^{c}$ Arithmetic mean for the strains of a cluster.

${ }^{d}$ ECL, equivalent chain length (25).

e Parentheses indicate that a fatty acid was detected in less than $66 \%$ of the strains of a cluster; such fatty acids were termed variable, and no arithmetic means were calculated for them.

${ }^{f} \mathrm{~B}$ denotes a specific but unknown position of the double bond.

TABLE 3. Fatty acid compositions of clusters and reference strains that had iso-anteiso fatty acid patterns

\begin{tabular}{|c|c|c|c|c|c|c|c|c|c|c|c|c|c|c|}
\hline \multirow[b]{3}{*}{$\begin{array}{l}\text { Fatty } \\
\text { acid }\end{array}$} & \multicolumn{14}{|c|}{$\%$ in $^{a}:$} \\
\hline & \multicolumn{2}{|c|}{$\begin{array}{l}\text { Cluster } 4 \\
(n=22)^{b}\end{array}$} & \multicolumn{2}{|c|}{$\begin{array}{c}\text { Cluster } 5 \\
(n=4)\end{array}$} & \multicolumn{2}{|c|}{$\begin{array}{c}\text { Cluster } 6 \\
(n=9)\end{array}$} & \multicolumn{8}{|c|}{ Reference strains } \\
\hline & $\operatorname{Mean}^{c}$ & Range & Mean & Range & Mean & Range & $\begin{array}{c}\text { "Coryne- } \\
\text { bacterium } \\
\text { mediola- } \\
\text { num" } \\
\text { DSM } \\
20152\end{array}$ & $\begin{array}{c}\text { Agro- } \\
\text { myces } \\
\text { ramosus } \\
\text { DSM } \\
43045^{\mathrm{T}}\end{array}$ & $\begin{array}{l}\text { Curtobac- } \\
\text { terium } \\
\text { flaccum- } \\
\text { faciens } \\
\text { DSM } 20129\end{array}$ & $\begin{array}{l}\text { B. linens } \\
\text { DSM } \\
20425^{\mathrm{T}}\end{array}$ & $\begin{array}{c}\text { Clavi- } \\
\text { bacter } \\
\text { michi- } \\
\text { ganense } \\
\text { DSM } \\
20134^{\mathrm{T}}\end{array}$ & $\begin{array}{c}\text { Curtobac- } \\
\text { terium } \\
\text { citreum } \\
\text { DSM } \\
20528^{T}\end{array}$ & $\begin{array}{c}\text { Aureo- } \\
\text { bacterium } \\
\text { lique- } \\
\text { faciens } \\
\text { DSM } \\
20638^{\mathrm{T}}\end{array}$ & $\begin{array}{l}\text { Microbac- } \\
\text { terium } \\
\text { lacticum } \\
\text { DSM } \\
20427^{\mathrm{T}}\end{array}$ \\
\hline anteiso-13:0 & - & - & 0.3 & $0-0.4$ & - & - & - & - & - & - & - & - & - & - \\
\hline iso-14:0 & 1.1 & $0.4-5.2$ & - & - & V & $(0-0.6)$ & 1.8 & - & 0.3 & 0.3 & 0.3 & 0.5 & 0.2 & 0.4 \\
\hline iso-15:0 & 29.2 & $13.5-45.2$ & 2.7 & $1.9-3.7$ & 1.6 & $1.0-3.0$ & 4.2 & 7.6 & 3.1 & 7.4 & 0.5 & 2.2 & 4.9 & 3.9 \\
\hline anteiso-15:0 & 46.1 & $28.2-61.1$ & 71.4 & $70.1-72.3$ & 47.0 & $41.2-51.0$ & 49.2 & 35.8 & 58.9 & 49.1 & 46.3 & 43.7 & 43.4 & 45.2 \\
\hline iso-16:0 & 4.7 & $1.3-14.7$ & 0.7 & $0.6-0.9$ & 6.1 & $3.4-7.9$ & 16.7 & 9.4 & 3.7 & 4.3 & 13.6 & 11.1 & 9.4 & 10.5 \\
\hline $16: 0$ & 0.9 & $0.3-1.3$ & 1.2 & $1.0-1.7$ & 0.7 & $0.7-3.4$ & 7.7 & 1.5 & 0.1 & 0.1 & 3.0 & 0.3 & 1.0 & 1.3 \\
\hline iso-17:0 & 1.5 & $0.5-3.6$ & - & - & 0.7 & $0-1.3$ & 0.8 & 4.8 & 0.6 & 2.7 & 0.4 & 0.9 & 3.6 & 3.8 \\
\hline anteiso-17:0 & 16.0 & $8.1-26.4$ & 23.4 & $22.5-24.7$ & 41.8 & $42.2-48.8$ & 17.1 & 41.0 & 33.4 & 36.0 & 33.1 & 41.2 & 37.2 & 34.6 \\
\hline 18:1-cis9 & 0.4 & $0-0.6$ & 0.3 & $0-0.5$ & 0.7 & $0.3-1.2$ & - & - & - & - & - & - & - & - \\
\hline
\end{tabular}

$a_{-}$, not detected; $\mathrm{V}$, variable (see Table 2 , footnote $e$ ). In addition, the following fatty acids were detected: cluster 4,0 to $0.5 \%$ iso-15:1G and $0.4 \%$ anteiso-15:1A in strain 2002/1 and $0.3 \% 14: 0$ and $0.4 \% 17: 0$ cyclo in strain $612 / 1$; cluster $5,0.2 \%$ iso-14:0 in strain $1073 / 1 ;$ cluster 6,0 to $1.0 \%$ anteiso-15:1; Clavibacter michiganense, $0.2 \% 14: 0,2.3 \%$ anteiso-15:1A, $0.2 \%$ unknown ECL 15.549, and 0.2\% iso-18:0; Curtobacterium citreum, 0.1\% iso-18:0; Aureobacterium liquefaciens, 0.2\% 17:1-cis10; Microbacterium lacticum, 0.2\% 17:0 and 0.2\% iso-18:0.

${ }^{b} n$ is the number of strains included in a cluster (see Table 1 ).

$c$ Arithmetic mean for the strains of a cluster. 
TABLE 4. Chemotaxonomic groups of the coryneform strains isolated from biofilters

\begin{tabular}{|c|c|c|c|c|c|c|c|c|c|}
\hline $\begin{array}{l}\text { FAME } \\
\text { cluster(s) }\end{array}$ & Taxon & $\begin{array}{c}\text { No. of } \\
\text { strain } \\
\text { analyzed }\end{array}$ & $\begin{array}{c}\text { Diamino } \\
\text { acid }^{a}\end{array}$ & $\begin{array}{l}\text { Arabi- } \\
\text { noga- } \\
\text { lactan }\end{array}$ & $\begin{array}{l}\text { Glycolyl } \\
\text { type of } \\
\text { pepti- } \\
\text { doglycan }\end{array}$ & $\begin{array}{l}\text { Mycolic } \\
\text { acids }^{b}\end{array}$ & $\begin{array}{l}\text { Fatty } \\
\text { acids }^{c}\end{array}$ & $\begin{array}{l}\text { Mena- } \\
\text { quinones }^{d}\end{array}$ & $\begin{array}{l}\text { Main polar } \\
\text { lipids }^{e}\end{array}$ \\
\hline 1 & Corynebacterium & $4^{f}$ & $m-\mathrm{A}_{2} \mathrm{pm}$ & + & - & $+(\mathrm{C})$ & $\mathrm{S}, \mathrm{U}$ & $\mathrm{MK}-8\left(\mathrm{H}_{2}\right)$ & DPG, PG, PI, PIM, $\mathrm{G}_{6}{ }^{g}$ \\
\hline 2 & $\begin{array}{l}\text { Corynebacterium } \\
\text { with TBSA }\end{array}$ & $11^{h}$ & $m-\mathrm{A}_{2} \mathrm{pm}$ & + & - & $+(\mathrm{C}-\mathrm{R})$ & $\mathrm{S}, \mathrm{U}, \mathrm{T}$ & $\mathrm{MK}-8\left(\mathrm{H}_{2}\right)$ & DPG, PG, PI, PIM, (PGL) \\
\hline \multirow[t]{2}{*}{3} & Gordona & $6^{i}$ & $m-\mathrm{A}_{2} \mathrm{pm}$ & + & + & $+(\mathbf{N})$ & $\mathrm{S}, \mathrm{U}, \mathrm{T}$ & MK-9 $\left(\mathrm{H}_{2}\right)^{j}$ & DPG, PE, PI, PIM, (PGL) \\
\hline & Mycobacterium & $2^{k}$ & $m-\mathrm{A}_{2} \mathrm{pm}$ & + & + & $+(\mathrm{M})$ & $\mathrm{S}, \mathrm{U}, \mathrm{T}$ & MK-9( $\left.\mathrm{H}_{2}\right)^{j}$ & DPG, PE, PI, PIM, (PGL) \\
\hline \multirow[t]{2}{*}{4 and 5} & Group A & $8^{l}$ & L-Lys ${ }^{m}$ & - & - & - & A, I & MK-7, MK- $8^{n}$ & $\begin{array}{l}\text { DPG, PG, }\left(\mathrm{P}_{1}\right),\left(\mathrm{P}_{2}\right),\left(\mathrm{P}_{3}\right), \\
\quad\left(\mathrm{P}_{4}\right), \mathrm{G}_{2},\left(\mathrm{G}_{3}\right),\left(\mathrm{G}_{4}\right)\end{array}$ \\
\hline & & $2^{o}$ & L-Lys & - & - & - & A, I & MK-8, MK- $\boldsymbol{~}^{p}$ & DPG, PG, $P_{1}, P_{2}, G_{2}, G_{3}, G_{4}$ \\
\hline 6 & Group B & $2^{q}$ & Dab & - & - & - & A, I & MK-11, MK-12 ${ }^{r}$ & DPG, PG, $G_{1}, G_{2}, G_{5}$ \\
\hline
\end{tabular}

${ }^{a} m$-A $\mathbf{A}_{2}$ pm, DL-diaminopimelic acid; L-Lys, L-lysine; Dab, diaminobutyric acid.

${ }^{b} \mathrm{C}$, corynemycolic acids; C-R, intermediate between corynemycolic acids and rhodomycolic acids; N, nocardomycolic acids; $\mathrm{M}$, eumycolic acids.

c S, straight chain, saturated; U, straight chain, monounsaturated; T, TBSA; A, anteiso-methyl-branched; I, iso-methyl-branched.

${ }^{d}$ MK, menaquinone. The number of isoprenyl groups in the side chain and the number of hydrogenated double bonds are indicated.

$e$ DPG, diphosphatidylglycerol; PG, phosphatidylglycerol; PI, phosphatidylinositol; PIM, phosphatidylinositol mannoside; PE, phosphatidylethanolamine; PGL, phosphoglycolipid that chromatographs close to the right of phosphatidylinositol; P, phospholipid; G, glycolipid that probably contains mannose and/or galactose residues $\left(G_{1}, G_{2}, G_{3}\right.$, and $\left.G_{6}\right)$ or glucose residues $\left(G_{4}\right.$ and $\left.G_{5}\right)$. The occurrence of lipids in parentheses was variable. For the chromatographic mobilities of the polar lipids of group A and B strains see Fig. 3.

$f$ Strains $2010 / 1,1094 / 1,1106 / 1$, and 337 .

$\boldsymbol{g}$ Glycolipid $\mathrm{G}_{6}$ containing mannose and/or glucose residues chromatographed just above phosphatidylinositol. Several additional glycolipids were detected.

${ }^{h}$ Strains 896/1, 1664/1, 1068/1, 1614/2,1026/2,1032/1, 1044/1,1503/1, 1069/1, 1348/1, and $1033 / 1$.

$i$ Strains $1730 / 11,1771 / 14,1767 / 12,1730 / 10,1610 / 1$, and $1534 / 1$.

${ }^{j} \mathrm{MK}-8\left(\mathrm{H}_{2}\right)$ was also present, but the amount of $\mathrm{MK}-8\left(\mathrm{H}_{2}\right)$ was less than $5 \%$ of the amount of $\mathrm{MK}-9\left(\mathrm{H}_{2}\right)$.

${ }^{k}$ Strains $1979 / 19$ and $2068 / 19$.

' Strains 1030/1, 1084/1, 1029/2, 2000/1, 815/2,1074/1, 1031/1, and 1073/1.

$m$ Detected in strains $1030 / 1,815 / 2$, and $1073 / 1$.

${ }^{n}$ MK-6 was detected in trace amounts. MK-7 and MK-8 were also detected in strains 1029/4, 1028/4, 1043/3, 1043/1, 612/1, 1104/1, 968/1, 810/1, 1105/4, and 1104/5.

- Strains 2002/1 and 1105/11.

P MK-7 was detected in trace amounts. The major component is in boldface type.

$q$ Strains $1038 / 2$ and $1109 / 1$

$r$ MK-9, MK-10, and MK-13 were detected in trace amounts.

containing taxa although it did not synthesize TBSA (Fig. 1). G. bronchialis DSM $43247^{\mathrm{T}}$ and $G$. rubropertinctus DSM $43197^{\mathrm{T}}$ were included in cluster 3 .

The strains which contained iso- and anteiso-branched fatty acids (Fig. 1) were clearly separated into cluster 4 (high levels of 13-methyltetradecanoic acid [iso-15:0]) and clusters 5 and 6 (low levels of iso-15:0) (Table 3). Cluster 4 and 5 strains contained 12-methyltetradecanoic acid (anteiso-15:0) in threefold-higher amounts than 14-methylhexadecanoic acid (anteiso-17:0), whereas cluster 6 strains contained the same fatty acids in about equal amounts (Table 3). Cluster 5 and 6 strains contained almost exclusively anteiso-branched fatty acids (up to $95 \%$ in cluster 5 [Table 3]). As shown in Fig. 1, clusters 5 and 6 are more closely related to each other than to cluster 4. Most of the reference strains clustered separately; the exception was "Corynebacterium mediolanum" DSM 20152, which was affiliated with cluster 6 at a Euclidian distance of 28 . Replicates of separately grown cultures used for fatty acid analyses clustered at Euclidian distances of less than 2. We observed quantitative differences in fatty acid composition (after a long incubation with continuous subculturing) (Euclidian distances, 13 to 16) for only two strains (strains 1074/1 and 2002/1); however, these findings had no effect on the cluster affiliation of these strains.

Additional chemotaxonomic analyses. Additional chemotaxonomic markers were used to evaluate the homogeneity of the fatty acid-based clusters and to allow for a more detailed characterization of the strains that we studied. In most cases affiliation at the genus level was achieved by combining the results for different biochemical markers. The results for selected strains belonging to the different clusters are shown in Table 4.
All of the strains with saturated-monounsaturated fatty acid patterns contained $m-\mathrm{A}_{2} \mathrm{pm}$ as the dominant diamino acid, arabinogalactan, mycolic acids, dihydrogenated menaquinones, phosphatidylinositol, and phosphatidylinositol mannoside. Strains containing the acetyl type of peptidogly-

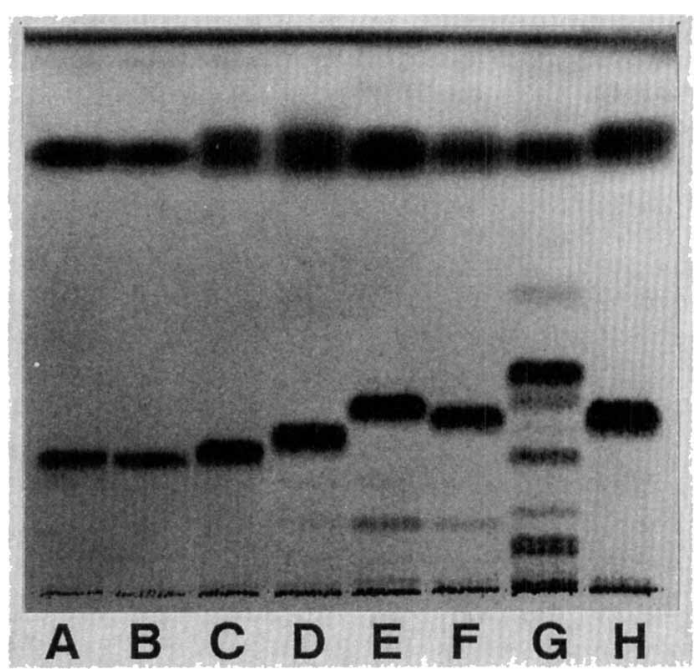

FIG. 2. Thin-layer chromatography of whole-organism methanolysates from selected strains belonging to clusters 1,2 , and 3 and type strains. Lane A, Corynebacterium glutamicum DSM $20300^{\mathrm{T}}$; lane B, strain 1094/1; lane C, strain 1026/2; lane D, R. rhodochrous DSM $43241^{\mathrm{T}}$; lane E, G. bronchialis DSM $43247^{\mathrm{T}}$; lane $\mathrm{F}$, strain 1610/1; lane G, strain 2068/19; lane H, N. asteroides DSM $43757^{\mathrm{T}}$. 
can, MK-8 $\left(\mathrm{H}_{2}\right)$, and phosphatidylglycerol were identified as Corynebacterium strains (7). Strains belonging to cluster 1 contained corynemycolic acids and an additional glycolipid, glycolipid $G_{6}$ (Table 4). Colonies of cluster 1 strains were yellow. The main differences between cluster 2 strains and cluster 1 strains were the presence in cluster 2 strains of TBSA and slightly longer mycolic acids that had mobilities on thin-layer chromatograms that were between the mobilities of corynemycolic acids and rhodomycolic acids (Fig. 2). In several strains an unidentified mannose- and/or galactosecontaining phosphoglycolipid was detected just to the right of phosphatidylinositol (phosphoglycolipid PGL). Colonies of these strains were bright to pale pink. Additional chemotaxonomic analyses revealed the presence of two genera in cluster 3. The strains which had a glycolyl type of peptidoglycan, nocardomycolic acids, TBSA, MK-9( $\left.\mathrm{H}_{2}\right)$, and the characteristic phosphatidylethanolamine and phosphoglycolipid PGL described above for Corynebacterium strains with TBSA were identified as Gordona strains (43). Mycobacterium strains had the same characteristics, but were clearly differentiated by their longer mycolic acids that produced multispot patterns on thin-layer chromatograms (Fig. 2) $(5,36)$.

All of the strains which produced iso-anteiso fatty acid patterns lacked $m-\mathrm{A}_{2} \mathrm{pm}$, arabinogalactan, and mycolic acids. These organisms had an acetyl type of peptidoglycan and completely unsaturated menaquinones and produced a simple polar lipid pattern containing diphosphatidylglycerol, phosphatidylglycerol, and some additional phospho- and glycolipids (Table 4). Two groups were identified; group A strains had L-lysine as the diamino acid, and group B strains had diaminobutyric acid as the diamino acid. The major menaquinones detected in the group A strains were either MK-7 and MK-8 or MK-8 and MK-9. Additional phospholipids detected were phospholipids $\mathrm{P}_{1}$ and $\mathrm{P}_{2}$ (Fig. $3 \mathrm{~b}$ ) or phospholipids $\mathrm{P}_{3}$ and $\mathrm{P}_{4}$ (Fig. 3a). The mannose- and/or galactose-containing glycolipids were glycolipids $G_{2}$ and $G_{3}$ (Fig. $3 a$ and $b$ ), whereas glycolipid $G_{4}$ contained glucose residues (Fig. 3b). The major menaquinones detected in group B strains were MK-11 and small amounts of MK-12. In addition, two mannose- and/or galactose-containing glycolipids (glycolipids $G_{1}$ and $G_{2}$ ) and a glucose-containing glycolipid (glycolipid $\mathrm{G}_{5}$ ) were detected (Fig. $3 \mathrm{c}$ ). The chromatographic mobilities of the mannose- and/or galactosecontaining glycolipids that have increasing polarity may correspond to the mobilities of monoglycosyldiacylglycerol (glycolipid $\mathrm{G}_{1}$ ), diglycosyldiacylglycerol (glycolipid $\mathrm{G}_{2}$ ), and triglycosyldiacylglycerol (glycolipid $\mathrm{G}_{3}$ ).

Determination of the peptidoglycan type. To further characterize the strains that produced iso-anteiso fatty acid patterns, it was necessary to determine the compositions and structures of the peptide moieties of their peptidoglycans. Table 5 shows the results of the quantitative amino acid analyses. The amino acid molar ratios for the peptidoglycans of strains 1030/1, 815/2, and 1073/1 (members of clusters 4 and 5) were consistent with the peptidoglycan type $A 4 \alpha$, L-Lys-Gly-L-Glu (38). The peptides L-Ala-D-Glu, N6-Gly-LLys, L-Lys-D-Ala, and $\mathbf{N}^{6}$-Gly-L-Lys-D-Ala were detected on a two-dimensional thin-layer chromatogram of the partial hydrolysates of the strains. Dinitrophenyl-Glu and $\varepsilon$-dinitrophenyl-Lys were found in nitrophenylated wall hydrolysates, confirming the $A 4 \alpha$ type of peptidoglycan with an interpeptide bridge of Gly-L-Glu. For strain 1105/11 a slightly different cell wall type with only lysine, glutamic acid, and alanine was detected. On a two-dimensional thin-layer chromatogram of the partial hydrolysate, the peptides L-Lys-D-
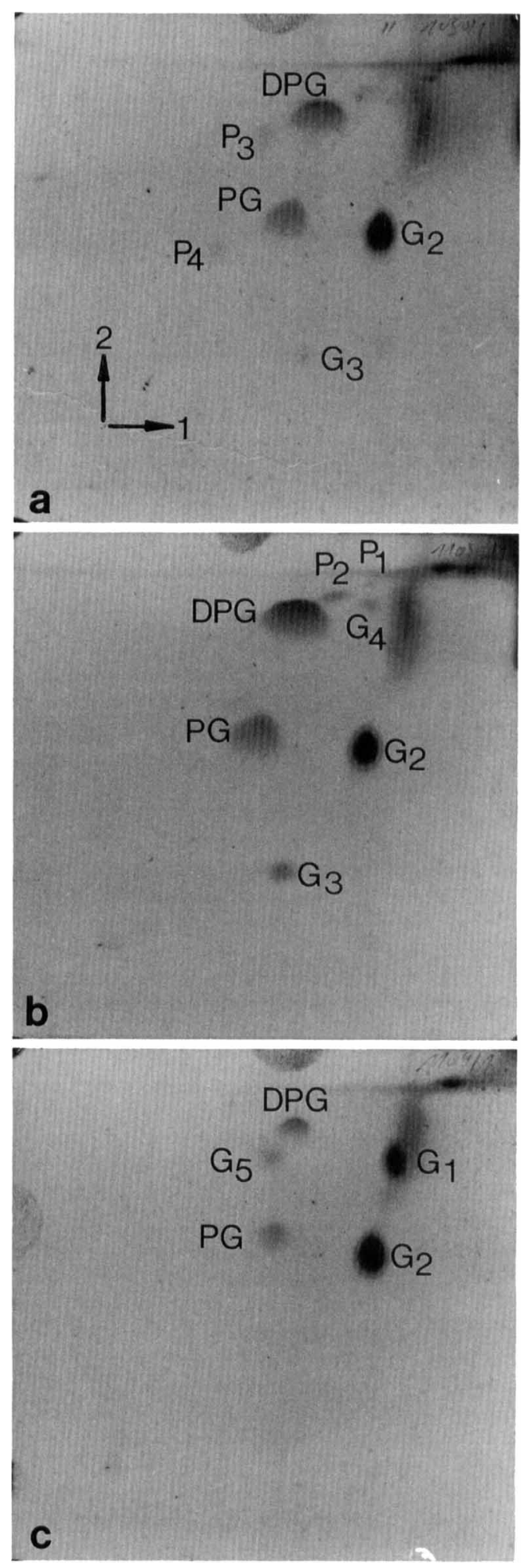

FIG. 3. Two-dimensional thin-layer chromatography of the polar lipids found in the strains that had iso-anteiso fatty acid patterns. Plates were sprayed with anisaldehyde- $\mathrm{H}_{2} \mathrm{SO}_{4}$ and were heated for $10 \mathrm{~min}$ at $150^{\circ} \mathrm{C}$. Abbreviations: DPG, diphosphatidylglycerol; PG, phosphatidylglycerol; P, phospholipid; G, glycolipid. (a) Group A strain 1030/1. (b) Group A strain 1105/11. (c) Group B strain 1109/1. 
TABLE 5. Amino acid molar ratios of cell wall peptidoglycans from coryneform strains that were isolated from biofilters and had iso-anteiso fatty acids ${ }^{a}$

\begin{tabular}{llllllll}
\hline \multirow{2}{*}{ Strain } & \multicolumn{7}{c}{ Molar ratios for the following components } \\
\cline { 2 - 7 } & Asp & Thr & Glu & Gly & Ala & Dab & Lys \\
\hline Group A strains & & & & & & & \\
$1030 / 1$ & & & 2 & 1.31 & 2.14 & & 1.21 \\
$815 / 2$ & & & 2 & 1.35 & 2.05 & & 1.21 \\
$1073 / 1$ & & & 2 & 1.24 & 2.10 & & 1.17 \\
Group B strain & & & & & & & \\
$1109 / 1$ & 1.22 & 1.00 & 1 & 1.10 & 1.71 & 1.07 & \\
\hline
\end{tabular}

a Abbreviations: Asp, aspartic acid; Thr, threonine; Glu, glutamic acid Gly, glycine; Ala, alanine; Dab, diaminobutyric acid; Lys, lysine.

$b$ Values are expressed as the molar ratios of the components to glutamic acid.

Ala and L-Ala-D-Glu were found. No characteristic peptide showing linkage to the $\varepsilon$-amino group of L-Lys was detected. This was only true if $\mathrm{L}-\mathrm{Glu}$ was connected to this group. Thus, the peptidoglycan type was A $4 \alpha$, L-Lys-L-Glu.

Analyses by two-dimensional thin-layer chromatography of the cell walls of two strains belonging to cluster 6 (strains $1038 / 2$ and $1109 / 1$ ) revealed the presence of aspartic acid, threonine, glutamic acid, glycine, alanine, and diaminobutyric acid in the peptidoglycan. The amino acid molar ratio for the peptidoglycan of strain $1109 / 1$ is shown in Table 5. The dipeptide Gly-D-Glu was detected in a partial hydrolysate of the cell walls, which indicated a type B peptidoglycan. In addition, dinitrophenyl-Asp was found in nitrophenylated cell walls. Such a combination of amino acids has not been described previously, and the peptidoglycan structure deduced from the information available so far is shown in Fig. 4.

Physiology. To examine whether the isolates could also be differentiated on the basis of physiological reactions, the strains which had saturated-monounsaturated fatty acid patterns (Table 6) and the strains which had iso-anteiso fatty acid patterns (Table 7) were studied.

The Corynebacterium strains without TBSA could be separated from the Corynebacterium strains with TBSA by the results of growth tests (Table 6). The physiological reactions of the Conynebacterium strains without TBSA were similar to the reactions of Corynebacterium pilosum
DSM $20521^{\mathrm{T}}$ and Conynebacterium renale DSM $20688^{\mathrm{T}}$, but were different from the reactions of the other reference strains (Table 6). Strains belonging to cluster 3 (Gordona and Mycobacterium strains) were divided into three taxa. Strains identified by chemotaxonomy as members of the genus Gordona were placed in taxa 3.1 and 3.3, and strains of the genus Mycobacterium exhibited different physiological reactions and formed taxon 3.2. G. bronchialis DSM $43247^{\mathrm{T}}$ was more similar in its reactions to taxon 3.1 than $G$. rubropertinctus DSM $43197^{\mathrm{T}}$ was.

The same physiological reactions were determined for the coryneform bacteria that had iso-anteiso fatty acid patterns. Since the strains were negative for most tests (tyrosine was remarkable in that it was decomposed slowly by several strains belonging to group A [data not shown]), no differentiation was possible on the basis of these reactions. Therefore, we performed additional physiological tests, including tests for hydrolysis of chromogenic substrates (Table 7). None of the isolates which contained iso- and anteiso fatty acids hydrolyzed a chromogenic substrate by action of glycosidases or phosphatases. Groups A and B were clearly differentiated on the basis of some chromogenic substrates for aminopeptidases. The group A strains exhibited more versatility in the assimilation of carbon sources than the group B strains. Growth on the fatty acids acetate, propionate, butyrate, isobutyrate, valerate, and isovalerate, as well as the utilization of DL-3-hydroxybutyrate and lactate, was quite common in group A strains, whereas caproate, heptanoate, caprylate, malate, citrate, and fructose supported growth of only a few isolates belonging to group A. Group B strains did not decompose the carbon sources mentioned above. No isolate belonging to group A or B utilized pyruvate, D-ribose, myo-inositol, and gluconate (data not shown).

\section{DISCUSSION}

Difierentiation and identification. Fatty acid analysis was used successfully to differentiate coryneform strains that were isolated from biofilters. Six clusters were identified on a dendrogram that was based on fatty acid composition. Three clusters contained strains with saturated and monounsaturated fatty acids, and three clusters contained strains with iso- and anteiso-branched fatty acids. The fatty acidbased clusters were confirmed by determining additional

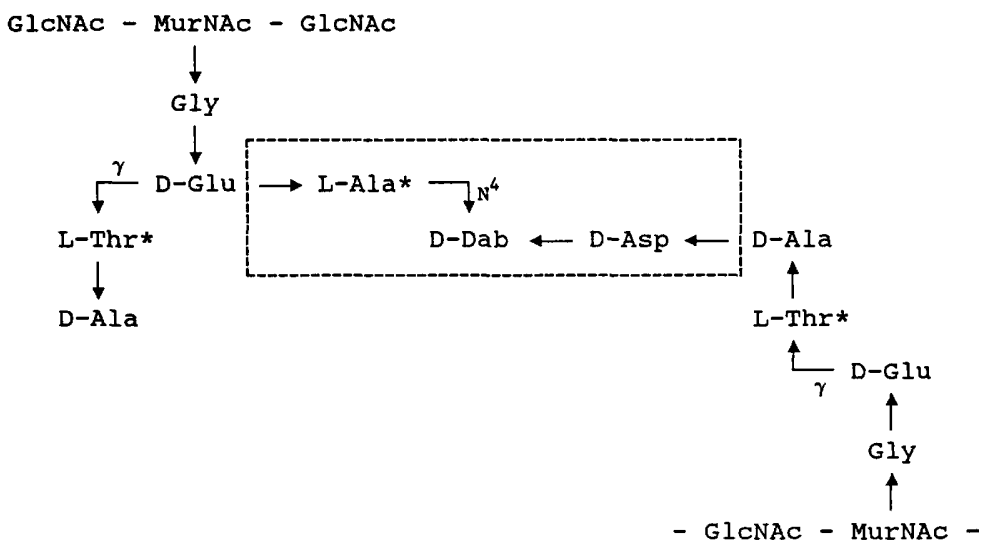

FIG. 4. Fragment of the peptidoglycan primary structure of strains belonging to group $\mathrm{B}$. The asterisks indicate that the positions of alanine or threonine in some locations have not been confirmed yet. GlcNAc, $N$-acetylglucosamine; MurNAc, $N$-acetylmuramic acid. For other abbreviations see Table 5, footnote $a$. 
TABLE 6. Physiological reactions of selected coryneform isolates obtained from biofilters and reference strains that had saturated-unsaturated fatty acid patterns ${ }^{a}$

\begin{tabular}{|c|c|c|c|c|c|c|c|c|c|c|c|c|}
\hline \multirow[b]{2}{*}{ Taxon } & \multirow{2}{*}{ 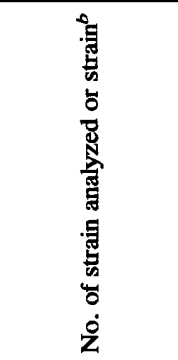 } & \multicolumn{11}{|c|}{ Growth on ${ }^{c}$ : } \\
\hline & & 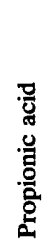 & 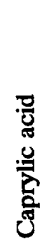 & 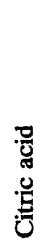 & 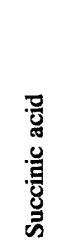 & 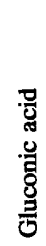 & 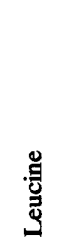 & 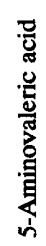 & 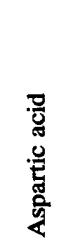 & 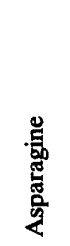 & $\begin{array}{l}\mathscr{0} \\
\text { : } \\
\text { : }\end{array}$ & 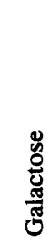 \\
\hline Corynebacterium sp. ${ }^{d}$ & 6 & + & - & - & + & - & - & - & + & + & + & \pm \\
\hline $\begin{array}{l}\text { Corynebacterium } \\
\text { pilosum }^{d}\end{array}$ & DSM $20521^{T}$ & + & + & - & + & - & - & - & $(+)$ & $(+)$ & + & + \\
\hline Corynebacterium renale ${ }^{d}$ & DSM $20688^{T}$ & - & - & - & + & - & - & - & + & + & + & $(+)$ \\
\hline $\begin{array}{l}\text { Corynebacterium } \\
\text { glutamicum }\end{array}$ & DSM $20300^{T}$ & + & - & + & + & + & - & - & - & - & + & - \\
\hline Corynebacterium xerosis & DSM $20743^{T}$ & + & + & - & $(+)$ & - & $(+)$ & + & $(+)$ & $(+)$ & $(+)$ & + \\
\hline $\begin{array}{l}\text { Corynebacterium } \\
\text { flavescens }\end{array}$ & DSM $20296^{T}$ & - & - & - & + & - & - & - & - & - & + & - \\
\hline $\begin{array}{l}\text { Corynebacterium sp. with } \\
\text { TBSA }\end{array}$ & 15 & + & + & - & - & - & - & - & $(+)$ & $(+)$ & - & - \\
\hline Gordona taxon 3.1 & 7 & + & \pm & + & + & - & + & - & - & - & - & $(+)$ \\
\hline Mycobacterium taxon 3.2 & 2 & + & - & - & - & + & - & - & - & - & + & - \\
\hline Gordona taxon 3.3 & 2 & + & + & - & - & - & - & - & - & - & - & - \\
\hline G. bronchialis & DSM $43247^{T}$ & + & + & - & + & - & + & - & - & - & - & $(+)$ \\
\hline G. rubropertinctus & DSM $43197^{T}$ & + & + & + & + & + & - & - & - & - & - & + \\
\hline
\end{tabular}

${ }^{a}$ All of the strains were negative for growth on adipic acid and arabinose and for hydrolysis of tyrosine, adenine and xanthine. None of the strains which we isolated produced acid from sucrose aerobically or anaerobically, and no strain of Corynebacterium sp. without TBSA which we isolated formed acid from glucose.

$b$ The following strains were tested: Corynebacterium sp. strains 1106/1, 1094/1, 1106/4, 2010/1, 2010/3, and 337; Corynebacterium sp. with TBSA strains 1068/1, $1032 / 1,1614 / 2,1664 / 1,1658 / 1,1044 / 1,1348 / 1,1503 / 1,1026 / 2,1023 / 7,1068 / 2,1026 / 5,1033 / 1,1069 / 1$, and 896/1; Gordona taxon 3.1 strains 1610/1, 1730/11, 1767/12, $1771 / 14,1730 / 10,1731 / 10$, and 1759/10; Mycobacterium taxon 3.2 strains 1979/19 and 2068/19; and Gordona taxon 3.3 strains 1534/1 and 1536/1.

$c+$, growth; (+), weak growth; - , no growth; \pm , different growth results for different strains.

d Positive reactions gave only weak growth.

chemical markers. Most of the clusters could also be separated on the basis of the results of physiological reactions. Genus identification of the clusters belonging to the saturated-unsaturated fatty acid group as the genus Corynebacterium (two Corynebacterium spp. were differentiated on the basis of occurrence of TBSA), the genus Gordona, and the genus Mycobacterium was achieved by combining the results obtained for the chemotaxonomic markers. Also on the basis of chemotaxonomy results, two clusters belonging to the iso-anteiso fatty acid group were affiliated with the "nicotianae" group of the genus Arthrobacter, and one cluster was affiliated with the coryneform bacteria which have type B peptidoglycans.

Corynebacterium sp. To identify the corynebacterial isolates in cluster 1 to the species level, the strains were compared with the corynebacterial type strains which possess MK- $8\left(\mathrm{H}_{2}\right)$ and lack TBSA (Corynebacterium renale DSM $20688^{\mathrm{T}}$ [8], Corynebacterium pilosum DSM $20521^{\mathrm{T}}$ [7], and Corynebacterium flavescens DSM $\left.20296^{\mathrm{T}}[8,48]\right)$. On the fatty acid dendrogram, only Corynebacterium pilosum DSM $20521^{\mathrm{T}}$ clustered close to cluster 1 (Fig. 1). Similarities to Corynebacterium pilosum DSM $20521^{\mathrm{T}}$, as well as Corynebacterium renale DSM $20688^{\mathrm{T}}$, were found in growth tests (Table 6), but identification as one of these reference strains was not possible because of the different fatty acid pattern of Corynebacterium renale and because separation of the trimethylsilylated mycolic acid methyl esters by gas chromatography revealed distinct differences with both type strains (23). The physiological reactions of all of the other reference strains (Table 6) as well as the different type of menaquinone [MK-9 $\left.\left(\mathrm{H}_{2}\right)\right]$ in Corynebacterium glutamicum $(15,48)$ and Corynebacterium xerosis (48), supported the differentiation already determined on the basis of fatty acid composition. In conclusion, no definitive species identification was possible.

Corynebacterium sp. with TBSA. Only a few other TBSAcontaining corynebacteria have been described previously. Corynebacterium bovis and Corynebacterium ammoniagenes possess MK- $9\left(\mathrm{H}_{2}\right)(8)$ and therefore differ from the strains which we isolated. In Corynebacterium variabilis and Corynebacterium polymorphus $\mathrm{MK}-8\left(\mathrm{H}_{2}\right)$ has been detected; however, MK-9( $\left.\mathrm{H}_{2}\right)$ has been the major menaquinone contained in these strains $(8,16)$. Also, in Corynebacterium minutissimum MK- $9\left(\mathrm{H}_{2}\right)$ has been found in greater amounts than MK- $8\left(\mathrm{H}_{2}\right)(10)$. Thus, there is no previously described species that has the combination of characteristics that the strains which we isolated have. Our strains seem to fall between the genera Corynebacterium and Rhodococcus. Like Rhodococcus strains, they possess TBSA in high concentrations and form pink colonies. However, like Corynebacterium strains, they possess phosphatidylglycerol PG and an acetyl type of peptidoglycan. The mycolic acids of these organisms were intermediate in length compared with corynemycolic acids and rhodomycolic acids.

The genera Gordona and Mycobacterium. Cluster 3 (Fig. 1) contained two taxa belonging to the genus Gordona and one taxon belonging to the genus Mycobacterium. These taxa could be separated clearly on the basis of physiology (Table 4). These taxa could also be identified on the fatty acid 
TABLE 7. Physiological reactions of selected coryneform isolates obtained from biofilters and reference strains that had iso-anteiso fatty acid patterns ${ }^{a}$

\begin{tabular}{|c|c|c|c|c|c|c|c|c|c|c|c|}
\hline \multirow[b]{2}{*}{ Strain(s) } & \multicolumn{11}{|c|}{ Hydrolysis of: } \\
\hline & 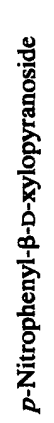 & 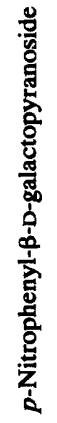 & 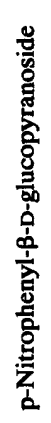 & 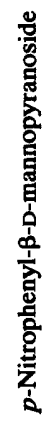 & 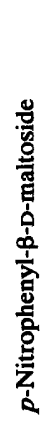 & 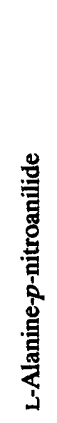 & 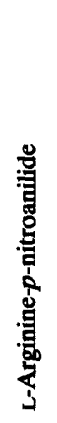 & 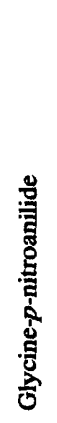 & 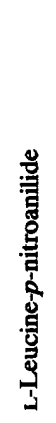 & 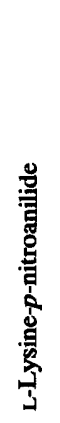 & 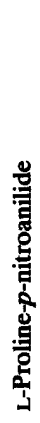 \\
\hline $\begin{array}{l}\text { Group A strains } 1074 / 1,1031 / 1 \text {, } \\
1105 / 11,1030 / 1,1084 / 1,1029 / 2, \\
\text { and } 968 / 1\end{array}$ & - & - & - & - & - & - & - & - & - & - & + \\
\hline $\begin{array}{l}\text { Group A strains } 815 / 2,1104 / 1 \text {, } \\
2000 / 1,810 / 1 \text {, and } 1073 / 1\end{array}$ & - & - & - & - & - & - & - & + & - & - & + \\
\hline Group B strain 1038/2 & - & - & - & - & - & + & + & - & + & + & - \\
\hline Group B strains $1103 / 8$ and $1109 / 1$ & - & - & - & - & - & + & - & - & + & + & - \\
\hline $\begin{array}{l}\text { Microbacterium lacticum DSM } \\
20427^{\mathrm{T}}\end{array}$ & - & + & + & - & - & + & + & + & + & + & + \\
\hline $\begin{array}{l}\text { Aureobacterium liquefaciens } \\
\text { DSM } 20638^{\mathrm{T}}\end{array}$ & + & - & + & - & - & + & + & + & + & + & + \\
\hline $\begin{array}{l}\text { Curtobacterium flaccumfaciens } \\
\text { DSM } 20129\end{array}$ & + & + & + & + & + & + & + & + & + & - & + \\
\hline
\end{tabular}

${ }^{a}$ No strain hydrolyzed $p$-nitrophenyl- $\beta$-D-glucuronide, $p$-nitrophenyl- $N$-acetyl- $\beta$-D-glucosaminide, $\gamma$-L-glutamate- $p$-nitroanilide, L-valine-p-nitroanilide, thymidine-5'-monophosphate-p-nitroanilide, $p$-nitrophenyl-phosphorylcholine, or bis-p-nitrophenyl-phosphate.

dendrogram even though the Euclidian distances were critically low. The strains belonging to taxon 3.1 and $G$. bronchialis DSM $43247^{\mathrm{T}}$ fell into a subcluster defined at a Euclidian distance of 7 (termed subcluster 3.1). The strains belonging to Mycobacterium taxon 3.2 clustered together at a Euclidian distance of 3, and the closest strain affiliated with this taxon (at a Euclidian distance of 5) was G. rubropertinctus DSM $43197^{\mathrm{T}}$ and formed subcluster 3.2. Subclusters 3.1 and 3.2 fused at a Euclidian distance of 9, and the link to taxon 3.3 occurred at a Euclidian distance of 12, which was defined as the upper limit of cluster 3. The two strains of taxon 3.3 were separated at a Euclidian distance of 10 , indicating a considerable difference despite the similarity in physiology. On the basis of fatty acid composition (Table 2) and physiological data (Table 6), it seems reasonable to place the strains belonging to taxon 3.1 near $G$. bronchialis. However, the mycolic acid methyl esters of Gordona strain $1610 / 1$ and the mycolic acid methyl esters of $G$. bronchialis DSM $43247^{\mathrm{T}}$ had different mobilities on thin-layer chromatograms (Fig. 2). The species affiliations of Gordona taxon 3.3 and Mycobacterium taxon 3.2 remain unresolved.

The close relationship among the genera Curtobacterium, Aureobacterium, Microbacterium, Agromyces, and Clavibacter $(12,17,42)$ is clearly demonstrated by the fatty acid patterns of these organisms. The members of all of the genera produce iso-anteiso fatty acid patterns, and no qualitative differences are found among these taxa. Therefore, it is very difficult (in most cases impossible) to differentiate these genera just on the basis of their fatty acid compositions. However, the strains which we isolated were separated from the reference strains on the FAME dendrogram (Fig. 1). The chemotaxonomic characteristics of the strains which we isolated were compared with those of known species and genera, and the closest affiliations which we identified are discussed below.

Group A. Strains belonging to clusters 4 and 5 were found to possess similar chemotaxonomic markers and therefore were placed in group A (Table 4 and Fig. 1). Cluster 4 was defined at a Euclidian distance of 29 , which indicated that there were substantial variations in the fatty acid compositions of the strains included (Table 3). Furthermore, variations were found in physiological reactions (Table 7), as well as in the presence of the chemical markers discussed below. The occurrence of peptidoglycan type A4 $\alpha$, L-Lys-Gly-L-Glu was combined with the presence of MK-7 and MK-8 (in ratios of 40:60 and 60:40, respectively), whereas peptidoglycan type A4 $\alpha$, L-Lys-L-Glu was found in strain 1105/11, which contained MK-8 and MK-9. Also, in strains 1105/11 and 2002/1 polar phosphlipids $P_{3}$ and $P_{4}$ were not detected (Table 4 and Fig. 3b). Thus, there was some heterogeneity among the strains belonging to cluster 4, which, however, was not resolved by fatty acid-based subclustering.

Cell wall structure is a good diagnostic feature for identification of coryneform bacteria. Peptidoglycan type A4 $\alpha$, L-Lys-Gly-L-Glu has been reported in Micrococcus luteus ATCC 398 (37), whose taxonomic position remains doubtful. However, this strain contains MK-9( $\left.\mathbf{H}_{2}\right)(49)$. The members of the "nicotianae" group of the genus Arthrobacter are characterized by iso-anteiso fatty acid patterns (the major fatty acid is anteiso-15:0, followed by iso-15:0, anteiso-17:0, and iso-16:0 [14]), a peptidoglycan of the A4 $\alpha$ type, completely unsaturated menaquinones of the MK-8 and MK-9 types (41), and polar lipid patterns containing diphosphatidylglycerol, phosphatidylglycerol, and a diglycosyldiacylglycerol $(14,41)$. The peptidoglycan structures of Arthrobacter nicotianae DSM $20123^{\mathrm{T}}$, Arthrobacter protophormiae 
TABLE 8. Menaquinones and peptidoglycans of the A4 $\alpha$ variation for the strains which we isolated and type strains belonging to the "nicotianae" group of the genus Arthrobacter

\begin{tabular}{|c|c|c|}
\hline Strain(s) & Menaquinones $^{a}$ & Peptidoglycan types \\
\hline $815 / 2,1030 / 1,1073 / 1$ & $(6), 7,8$ & L-Lys-Gly-L-Glu \\
\hline $1105 / 11$ & $(7), 8,9$ & L-Lys-L-G̈lu \\
\hline $\begin{array}{l}\text { Arthrobacter nicotianae DSM } 20123^{\mathrm{T}} \text { and Arthrobacter protophormiae } \\
\text { DSM } 20168^{\mathrm{T} b}\end{array}$ & $(7), 8,9$ & L-Lys-L-Ala-L-Glu \\
\hline Arthrobacter uratoxydans ATCC $21749^{\mathrm{T}}$ & $(7), 8,(9)$ & L-Lys-L-Ala-L-Glu \\
\hline Arthrobacter sulfureus DSM $20167^{\mathrm{T} b}$ & $(8), 9,10$ & L-Lys-L-Glu \\
\hline
\end{tabular}

${ }^{a}$ Number of completely unsaturated isoprenoid side chains. The major menaquinones are in boldface type; parentheses indicate minor menaquinones.

$b$ Data for strains DSM $20123^{\mathrm{T}}$ and DSM $20167^{\mathrm{T}}$ were obtained from references 14 and 41.

DSM $20168^{\mathrm{T}}$, and Arthrobacter uratoxydans ATCC $21749^{\mathrm{T}}$ were found to be similar to those of strains $815 / 2,1030 / 1$, and 1073/1 with MK-7 and MK-8, except that L-alanine in the interpeptide bridge of the reference strains was replaced by glycine in the strains which we isolated (Table 8). Arthrobacter sulfureus DSM $20167^{\mathrm{T}}$ had the same peptidoglycan structure as strain 1105/11 (L-Lys-L-Glu), but the menaquinone compositions of these organisms were not identical (Table 8). Despite differences in chemical markers and physiology $(19,41)$, Stackebrandt et al. (41) found DNA relatedness values of more than $20 \%$ among the strains belonging to the "nicotianae" group, thus separating this group from the "globiformis" group of Arthrobacter strains that possess MK- $9\left(\mathrm{H}_{2}\right)$ and an $\mathrm{A} 3 \alpha$ type of peptidoglycan (41). Therefore, mainly on the basis of chemical markers, it is reasonable to place the strains which we isolated in the "nicotianae" group of the genus Arthrobacter. The ability of most of the strains which we isolated to utilize several short-chain fatty acids is in accord with the physiological versatility described previously for the "nicotianae" group of the genus Arthrobacter (41). The characteristics of the strains which we isolated indicate that the variability and combination of chemical markers (menaquinone composition, peptidoglycan structure) in the members of the "nicotianae" group of the genus Arthrobacter are still more divergent than the characteristics described previously (22, 41). It has been suggested that the genus Arthrobacter should be further restricted to those species which contain type $\mathrm{A} 3 \alpha$ peptidoglycans and $\mathrm{MK}-9\left(\mathrm{H}_{2}\right)(22)$. Thus, there is a need for a valid description of the "nicotianae" group of organisms.

Group B. Group B was clearly separated from the other bacteria that produced iso-anteiso fatty acid patterns on the FAME dendrogram (Fig. 1), as well as by the results of the additional chemotaxonomic analyses (Table 4 ) and the physiology studies (Table 7). The type B peptidoglycan and MK-11, together with a small amount of MK-12, placed the strains which we isolated close to other diaminobutyric acid-containing coryneform bacteria that also possess unusually long menaquinones, including "Corynebacterium mediolanum" DSM 20152 and "Flavobacterium dehydrogenans" NCMB 872 (MK-12 and MK-11 [9]), "Corynebacterium aquaticum" DSM 20146 (MK-11 and MK-10 [9]), "Corynebacterium okanaganae" (MK-11 and MK-12 [11]), and Agromyces ramosus (MK-12 and MK-13 [6]). Further support for the hypothesis that these organisms are related came from the simple polar lipid patterns of the reference strains (diphosphatidylglycerol, phosphatidylglycerol, and several glycolipids that probably contain mannose residues) (9). However, the unique amino acid composition (Table 5) and the structure of the peptidoglycan (Fig. 4) of the group B strains distinguish them from "Corynebacterium aquati- cum," "Corynebacterium mediolanum," Agromyces ramosus, and Clavibacter michiganense, which lack aspartic acid and threonine (18). The acetyl type of peptidoglycan of the strains which we isolated and other chemical markers were not in accord with the characteristics of other coryneform bacteria with a type B peptidoglycan, such as Aureobacterium and Microbacterium strains, which contain glycolyl and acetyl residues $(12,13)$.

On the basis of the results of chemotaxonomic studies and some physiological tests, we found similarities between isolated coryneform strains and type strains in some cases, whereas in other cases new characteristics or new combinations of chemical markers were observed. This suggests that several new species were isolated or that our species concept was too narrow. Conclusive evidence about the identity or synonymy of the strains might be achieved by using DNA hybridization.

In this study numerical analysis of bacterial fatty acid composition was useful for differentiating unknown coryneform bacteria that were isolated from biofilters. Since other areas of environmental microbiology or biotechnology, including biofiltration, are also in need of rapid differentiation methods for a broad spectrum of coryneform bacteria, the procedure which we described above may also be applicable in those areas. Furthermore, this method allows for correct taxonomic group affiliation, thereby avoiding misnaming of strains. Moreover, this information is invaluable for further identification of strains based on chemotaxonomy or DNA techniques.

\section{ACKNOWLEDGMENTS}

We thank Norbert Weiss (DSM-Deutsche Sammlung von Mikroorganismen und Zellkulturen GmbH, Braunschweig, Germany) for advice on analyses and interpretation of amino acid compositions of peptidoglycans, Peter Schumann (DSM-Deutsche Sammlung von Mikroorganismen und Zellkulturen GmbH, Jena, Germany) for contributions to cell wall analyses, Roland Schmid (Abteilung für Mikrobiologie, Universität Osnabrück, Osnabrück, Germany) for quantitative amino acid analyses, and Gabi Pötter (DSM-Deutsche Sammlung von Mikroorganismen und Zellkulturen) for technical assistance.

This work was supported by the Ministerium für Wissenschaft und Kultur des Landes Niedersachsen, the Fonds der Chemischen Industrie, and the DECHEMA e.V., Frankfurt am Main, Germany, through a fellowship to B.B.

\section{REFERENCES}

1. Becker, B., M. P. Lechevalier, R. E. Gordon, and H. A. Lechevalier. 1964. Rapid differentiation between Nocardia and Streptomyces by paper chromatography of whole-cell hydrolysates. Appl. Microbiol. 12:421-423.

2. Bendinger, B. 1992. Ph.D. thesis. University of Osnabück, Osnabrück, Germany. 
3. Bendinger, B., R. M. Kroppenstedt, H. Rijnaarts, H. R. Van Langenhove, R. C. Oberthür, and K. Altendorf. 1990. Studies on the microbiology and degradation capacities of a biofilter, $\mathrm{p}$. 529-533. In D. Behrens and P. Krämer (ed.), DECHEMA Biotechnology Conferences, vol. 4A. VCH Verlagsgesellschaft, Weinheim, Germany.

4. Bousfield, I. J., G. L. Smith, T. R. Dando, and G. Hobbs. 1983. Numerical analysis of total fatty acid profiles in the identification of coryneform, nocardioform and some other bacteria. J. Gen. Microbiol. 129:375-394.

5. Brennan, P. J. 1988. Mycobacterium and other actinomycetes, p. 203-298. In C. Ratledge and S. G. Wilkinson (ed.), Microbial lipids, vol. 1. Academic Press, London.

6. Collins, M. D. 1982. Lipid composition of Agromyces ramosus (Gledhill and Casida). FEMS Microbiol. Lett. 14:187-189.

7. Collins, M. D., and C. S. Cummins. 1986. Genus Corynebacterium Lehmann and Neumann 1986, 350 AL, p. 1266-1276. In P. H. A. Sneath, N. S. Mair, M. E. Sharpe, and J. G. Holt (ed.), Bergey's manual of systematic bacteriology, vol. 2. The Williams \& Wilkins Co., Baltimore.

8. Collins, M. D., M. Goodfellow, and D. E. Minnikin. 1979. Isoprenoid quinones in the classification of coryneform and related bacteria. J. Gen. Microbiol. 110:127-136.

9. Collins, M. D., and D. Jones. 1980. Lipids in the classification and identification of coryneform bacteria containing peptidoglycans based on 2,4-diaminobutyric acid. J. Appl. Bacteriol. 48: $459-470$.

10. Collins, M. D., and D. Jones. 1981. Distribution of isoprenoid quinone structural types in bacteria and their taxonomic implications. Microbiol. Rev. 45:316-345.

11. Collins, M. D., and D. Jones. 1981. Lipid composition of the entomopathogen Corynebacterium okanaganae (Lüthy). FEMS Microbiol. Lett. 10:157-159.

12. Collins, M. D., D. Jones, R. M. Keddie, R. M. Kroppenstedt, and K. H. Schleifer. 1983. Classification of some coryneform bacteria in a new genus Aureobacterium. Syst. Appl. Microbiol. 4:236-252.

13. Collins, M. D., D. Jones, and R. M. Kroppenstedt. 1983. Reclassification of Brevibacterium imperiale (Steinhaus) and "Conynebacterium laevaniformans" (Dias and Bhat) in a redefined genus Microbacterium imperiale comb. nov. and Microbacterium laevaniformans nom. rev. comb. nov. Syst. Appl. Microbiol. 4:65-78.

14. Collins, M. D., and R. M. Kroppenstedt. 1983. Lipid composition as a guide to the classification of some coryneform bacteria containing an A4 $\alpha$ type peptidoglycan (Schleifer and Kandler). Syst. Appl. Microbiol. 4:95-104.

15. Collins, M. D., T. Pirouz, M. Goodfellow, and D. E. Minnikin. 1977. Distribution of menaquinones in actinomycetes and corynebacteria. J. Gen. Microbiol. 100:221-230.

16. Collins, M. D., H. N. Shah, and D. E. Minnikin. 1980. A note on the separation of natural mixtures of bacterial menaquinones using reverse phase thin-layer chromatography. J. Appl. Bacteriol. 48:277-282.

17. Döpfer, H., E. Stackebrandt, and F. Fiedler. 1982. Nucleic acid hybridization studies on Microbacterium, Curtobacterium and related taxa. J. Gen. Microbiol, 128:1697-1708.

18. Fiedler, F., and O. Kandler. 1973. Die Aminosäuresequenz von 2,4-Diaminobuttersäure enthaltenden Mureinen bei verschiedenen coryneformen Bakterien und Agromyces ramosus. Arch. Mikrobiol. 89:51-66.

19. Grund, E. 1987. Ph.D. thesis. Technische Hochschule Darmstadt, Darmstadt, Germany.

20. Henningson, P. J., and N. C. Gudmestad. 1991. Fatty acid analysis of phytopathogenic coryneform bacteria. J. Gen. Microbiol. 137:427-440.

21. Hippchen, B. 1985. Mikrobiologische Untersuchungen zur Eliminierung organischer Lösungsmittel im Biofilter. Stuttgarter Berichte zur Siedlungswasserwirtschaft 94. Oldenbourg-Verlag, Munich.

22. Keddie, R. M., M. D. Collins, and D. Jones. 1986. Genus Arthrobacter Conn and Dimmick $1947,300^{\mathrm{AL}}$, p. 1288-1301. In P. H. A. Sneath, N. S. Mair, M. E. Sharpe, and J. G. Holt (ed.),
Bergey's manual of systematic bacteriology, vol. 2. The Williams \& Wilkins Co., Baltimore.

23. Klatte, S. Unpublished data.

24. Kroppenstedt, R. M. 1979. Chromatographische Identifizierung von Mikroorganismen dargestellt am Beispiel der Actinomyceten. Kontakte 2:12-21.

25. Kroppenstedt, R. M. 1985 . Fatty acid and menaquinone analysis of actinomycetes and related organisms. Soc. Appl. Bacteriol. Tech. Ser. 20:173-199.

26. Kroppenstedt, R. M., and H. J. Kutzner. 1978. Biochemical taxonomy of some problem actinomycetes. Zentralbl. Bakteriol. Parasitenkd. Infektionskr. Hyg. Abt. 1 Orig. Suppl. 6:125133.

27. Kroppenstedt, R. M., E. Stackebrandt, and M. Goodfellow. 1990. Taxonomic revision of the actinomycete genera Actinomadura and Microtetraspora. Syst. Appl. Microbiol. 13:148 160.

28. Lechevalier, M. P. 1968. Identification of aerobic actinomycetes of clinical importance. J. Lab. Clin. Med. 71:934-944.

29. Lechevalier, M. P., C. De Bievre, and H. A. Lechevalier. 1977. Chemotaxonomy of aerobic actinomycetes: phospholipid composition. Biochem. Syst. Ecol. 5:249-260.

30. Lechevalier, M. P., A. C. Horan, and H. A. Lechevalier. 1971. Lipid composition in the classification of nocardiae and mycobacteria. J. Bacteriol. 105:313-318.

31. Lechevalier, M. P., and H. A. Lechevalier. 1970. Chemical composition as a criterion in the classification of aerobic actinomycetes. Int. J. Syst. Bacteriol. 20:435-444.

32. Lemmer, H., and R. M. Kroppenstedt. 1984. Chemotaxonomy and physiology of some actinomycetes isolated from scumming activated sludge. Syst. Appl. Microbiol. 5:124-135.

33. Lipski, A., S. Klatte, B. Bendinger, and K. Altendorf. 1992. Differentiation of gram-negative, nonfermentative bacteria isolated from biofilters on the basis of fatty acid composition, quinone system, and physiological reaction profiles. Appl. Environ. Microbiol. 58:2053-2065.

34. Minnikin, D. E., L. Alshamaony, and M. Goodfellow. 1975. Differentiation of Mycobacterium, Nocardia and related taxa by thin-layer chromatography analysis of whole cell organism methanolysates. J. Gen. Microbiol. 88:200-204.

35. Minnikin, D. E., A. G. O'Donell, M. Goodfellow, G. Alderson, M. Athalye, A. Schaal, and J. H. Parlett. 1984. An integrated procedure for the extraction of bacterial isoprenoid quinones and polar lipids. J. Microbiol. Methods 2:233-241.

36. Minnikin, D. E., P. V. Patel, L. Alshamaony, and M. Goodfellow. 1977. Polar lipid composition in the classification of Nocardia and related bacteria. Int. J. Syst. Bacteriol. 27:104-117.

37. Niebler, E., K. H. Schleifer, and O. Kandler. 1969. The amino acid sequence of the L-glutamic acid containing mureins of Micrococcus luteus and M. freudenreichii. Biochem. Biophys. Res. Commun. 34:560-568.

38. Schleifer, K. H., and O. Kandler. 1972. Peptidoglycan types of bacterial cell walls and their taxonomic implications. Bacteriol. Rev. 36:402-477.

39. Seiler, H. 1983. Identification key for coryneform bacteria derived by numerical taxonomic studies. J. Gen. Microbiol. 129:1433-1471.

40. Skerman, V. B. D., V. McGowan, and P. H. A. Sneath (ed.). 1980. Approved lists of bacterial names. Int. J. Syst. Bacteriol. 30:225-240.

41. Stackebrandt, E., V. J. Fowler, F. Fiedler, and H. Seiler. 1983. Taxonomic studies on Arthrobacter nicotianae and related taxa: description of Arthrobacter uratoxydans sp. nov. and Arthrobacter sulfureus sp. nov. and reclassification of Brevibacterium protophormiae as Arthrobacter protophormiae comb. nov., Syst. Appl. Microbiol. 4:470-486.

42. Stackebrandt, E., and K. H. Schleifer. 1984. Molecular systematics of actinomycetes and related organisms, p. 485-504. In L. Ortiz-Ortiz, L. F. Bojalil, and V. Jakoleff (ed.), Biological, biochemical, and biomedical aspects of actinomycetes. Academic Press, New York.

43. Stackebrandt, E., J. Smida, and M. D. Collins. 1988. Evidence of phylogenetic heterogeneity within the genus Rhodococcus: 
revival of the genus Gordona (Tsukamura). J. Gen. Appl. Microbiol. 34:341-348.

44. Stanek, J. L., and G. D. Roberts. 1974. Simplified approach to identification of aerobic actinomycetes by thin-layer chromatography. Appl. Microbiol. 28:226-231.

45. Suzuki, K.-I., and K. Komagata. 1983. Taxonomic significance of cellular fatty acid composition in some coryneform bacteria. Int. J. Syst. Bacteriol. 33:188-200.

46. Uchida, K., and K. Aida. 1977. Acyl type of bacterial cell wall: its simple identification by colorimetric method. J. Gen. Microbiol. 23:249-260.

47. Van Langenhove, H. R., F. A. Van Wassenhove, J. K. Coppin,
M. R. Van Acker, and N. M. Schamp. 1982. Gas chromatography/mass spectrometry identification of organic volatiles contributing to rendering odors. Environ. Sci. Technol. 16:883-886.

48. Yamada, Y., G. Inouye, Y. Tahara, and K. Kondo. 1976. The menaquinone system in the classification of coryneform and nocardioform bacteria and related organisms. J. Gen. Appl. Microbiol. 22:203-214.

49. Yamada, Y., G. Inouye, Y. Tahara, and K. Kondo. 1976. The menaquinone system in the classification of aerobic Grampositive cocci in the genera Micrococcus, Staphylococcus, Planococcus and Sporosarcina. J. Gen. Appl. Microbiol. 22: 227-236. 